\title{
The Immunoelectron Microscopic Detection of a Gonadotrophin-like Substance in Mouse Embryos
}

\author{
Sueo NiImUra, Akira Narita* and Kazuo Ishida \\ Faculty of Agriculture and *Graduate School of Science and \\ Technology, Niigata University, Niigata-shi 950-21
}

(Received July 10, 1989)

Key words : immunoelectron microscopy, gonadotrophin-like substance, mouse embryo

The detection of a gonadotrophin-like substance in mammalian embryos was first reported by HAOUR and SAXENA ${ }^{1)}$ in 1974. They detected, by radioreceptorassay, a substance similar to human chorionic gonadotrophin (hCG) or luteinizing hormone ( $\mathrm{LH})$ in rabbit blastocysts 6 days post coitum, and suggested that rabbit embryos had the ability to synthesize the substance. The substance has since been re-detected in rabbit blastocysts by radioreceptorassay ${ }^{2,3)}$ and radioimmunoassay $^{4-6)}$.

The substance has also been detected by both the immunofluorescence method and immunoperoxidase method in the embryos of rabbits ${ }^{3,7}$, mice ${ }^{8)}$ and rats $^{9)}$. By such immunostaining methods, it has been reported that fluorescence or dark brown products showing the presence of the substance can be observed on the cell surfaces of blastomeres in the morulae of rabbits $^{7)}$ and in 8-cell embryos and in the morulae of mice ${ }^{8)}$ and rats $^{9)}$, while the blastocysts of those animals ${ }^{3,8,9)}$ showed fluorescence only on the trophoblast-cell surfaces. Though the localization of the gonadotrophin-like substance in the embryos has been reported above, the localization was indistinct as far as we examined their inserted microphotographs $^{3,7,9)}$. We suspected it may have been caused by the use of whole-mounted embryos ${ }^{3.7}$ or paraffin-sectioned embryos ${ }^{9}$.

In this immunohistochemical investigation, therefore, we employed transmission electronmicroscopy, in order to clarify the precise localization of the gonadotrophin-like substance in mouse eggs and embryos at their various developmental stages.

\section{Materials and Methods}

ICR female mice, 8 weeks old, were superovulated first with 5i.u. PMSG (Serotropin, Teikoku Hormone Manufacturing Co., Ltd.), and then injected with 5i.u. hCG (Gonatropin, Teikoku Hormone Manufacturing Co., Ltd.) 48 hrs later. They were mated with males of proven fertility. The eggs and embryos were collected at the following points of time by flushing oviducts or uteri with phosphatebuffered saline ${ }^{10)}$ (PBS, pH 7.4); 24 hrs after hCG injection to obtain pronuclear eggs ; 48 hrs after, for 2-cell embryos ; $60 \mathrm{hrs,} \mathrm{for} \mathrm{4-cell}$ embryos ; $67 \mathrm{hrs,}$ for 8-cell embryos ; $80 \mathrm{hrs,}$

マウス脹におけるゴナドトロピン様物質の免疫電顕的検出 : 新村末雄・成田 成 ${ }^{1)}$. 石田一夫 (新潟大学農学部・

1) 新舅大学自然科学研桇科 新潟市 950-21) 
for morulae ; and $96 \mathrm{hrs}$, for blastocysts. Unfertilized eggs were also collected from the oviducts of unmated females $24 \mathrm{hrs}$ after hCG injection.

The zonae pellucidae of eggs and embryos were removed in PBS that contained $0.2 \%$ pronase (Sigma, U.S.A.). Cumulus cells surrounding unfertilized eggs were dissolved beforehand in PBS that contained $0.1 \%$ hyaluronidase (Sigma). The naked eggs and embryos were washed in PBS and fixed in PLP medium ( $\mathrm{pH} 6.2$ ) for $4 \mathrm{hrs}$ at $4^{\circ} \mathrm{C}$. The composition of the PLP medium was $10 \mathrm{mM}$ sodium m-periodate (Nakarai Chemicals, Ltd.), $75 \mathrm{mM}$ L-lysine (Nakarai Chemicals,Ltd.), 2\% paraformaldehyde (Nakarai Chemicals, Ltd.) and $100 \mathrm{mM}$ phosphate buffer solution. The eggs and embryos were further rinsed overnight in PBS at $4^{\circ} \mathrm{C}$, and then incubated in the rabbit anti-hCG serum (UCB-Bioproducts, Belgium) for $8 \mathrm{hrs}$. The anti-hCG serum was diluted 40 times with PBS. The antiserum reacts with hCG $\beta(55 \%)$, hLH (45\%), hCG (39\%), hCG $\alpha$ $(15 \%)$, hFSH $(5 \%)$, hTSH $(5 \%)$ and not with hPRL, hGH, hPL or hACTH. The eggs and embryos treated with the antiserum were rinsed 3 times in PBS for a total of $60 \mathrm{~min}$, and then incubated overnight in the goat anti-rabbit IgG conjugated with peroxidase (Cappel, U.S.A.). The goat anti-rabbit IgG conjugated with peroxidase was diluted 32 times with PBS. The eggs and embryos were rinsed in PBS and fixed again in $1 \%$ glutaraldehyde $100 \mathrm{mM}$ phosphate buffer solution ( $\mathrm{pH}$ 7.4) for $60 \mathrm{~min}$. The control eggs and embryos were incubated in normal rabbit serum $(1: 40)$ prior to the peroxidase treatment, or singly in the peroxidase conjugate. All these procedures were carried out in a moist chamber at $4^{\circ} \mathrm{C}$. After fixation, the eggs and embryos were rinsed overnight in PBS at $4^{\circ} \mathrm{C}$ and then incubated in $\mathrm{DAB}$ medium, that was composed of $20 \mathrm{mg} 3-3^{\prime}-$ diaminobenzidine tetrahydrochloride (Nakarai Chemicals,Ltd.) and $100 \mathrm{ml}$ of $50 \mathrm{mM}$ tris- $\mathrm{HCl}$ buffer solution ( $\mathrm{pH} \mathrm{7.6)}$, for $30 \mathrm{~min}$ at room temperature. They were immediately incubated in $\mathrm{DAB}$ medium, that contained $0.1 \mathrm{~m} l$ of $5 \%$ hydrogen peroxide solution, for a few minutes at room temperature and then postfixed in $100 \mathrm{mM}$ phosphate buffer solution ( $\mathrm{pH} \mathrm{7.4)} \mathrm{that}$ contained $2 \%$ osmium tetraoxide, for $60 \mathrm{~min}$ at $4^{\circ} \mathrm{C}$.

All the eggs and embryos prepared for the detection of the substance were dehydrated in graded series of acetone, embedded in Epon 812 , and cut with an ultramicrotome (JUM-7). These preparations were photographed through an electron microscope (JEM-100B).

\section{Results and Discussion}

Treated with an antiserum to hCG and with an anti-rabbit IgG conjugated with peroxidase for the detection of a gonadotrophin-like substance, osmium black, high in electron density, was deposited on the outer surfaces of the cytoplasmic membranes of the mouse embryos at the stages of 4-cell to blastocyst (Fig. 1-a), but not on those of 1-cell eggs and 2-cell embryos. There were no such deposits observed on the cytoplasmic membranes of the embryos at the stages of 4-cell to blastocyst when incubated in normal rabbit serum or in peroxidase conjugate only (Fig. 1-b).

In the blastomeres of the embryos at 4-cell through morula stages, the osmium black was deposited only on their cytoplasmic membranes facing the perivitelline space. In blastocysts, the deposits on the cytoplasmic membranes were restricted in the trophoblast cells facing the perivitelline space, but were not observed in other parts of the trophoblast cells nor in any part of the inner-cell-mass cells. The amount of the deposits on the cytoplasmic membranes was abundant in the embryos at 8-cell through blastocyst stages, although such was very little in those at 4-cell stage.

The results from this electron-immunohistochemical experiments elucidated for the first time the cellular localization of an hCG- or LH-like substance in mammalian embryos, and 


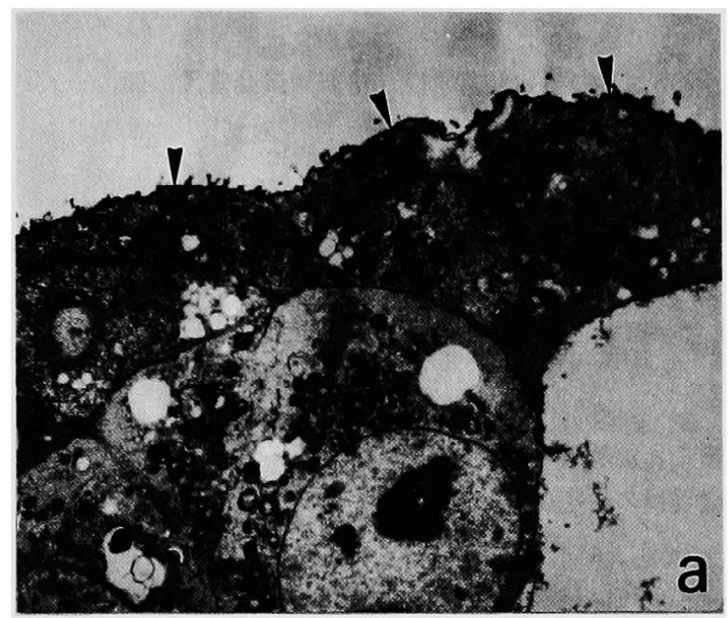

Fig. 1-a. A mouse blastocyst treated with an antiserum to hCG and with an anti-rabbit IgG conjugated with peroxidase. Osmium black (arrowheads) showing the presence of a substance similar to hCG or LH is deposited on the outer surfaces of the cytoplasmic membranes only of trophoblast cells facing the perivitelline space. $\times 2500$.

demonstrated the presence of the substance in mouse embryos not only in the stages of 8-cell through blastocyst but in the 4-cell stage also.

According to $\mathrm{WILEY}^{8)}$ who has immunohistochemically attempted to demonstrate the substance in mouse embryos at preimplantation stages, the fluorescence showing the presence of the substance was observed on the cell surface of the embryos at 8-cell through blastocyst stages. WILEY ${ }^{8)}$, then, suggested that mouse embryos must be capable of synthesizing the substance, since he found the same substance in the embryos cultured from 2-cell stage on.

Concerning the mouse embryo's developmental stages at which the substance appeared, the results of the present experiment differ from those of WILEY ${ }^{8)}$, his from 8-cell stage on and ours 4-cell on. The discrepancy may be due to the sensitivity of the methods used to detect the substance. In order to visualize such substance, moreover, we consider the electron-immunohistochemical method employed in our study is better than the immunofluorescence

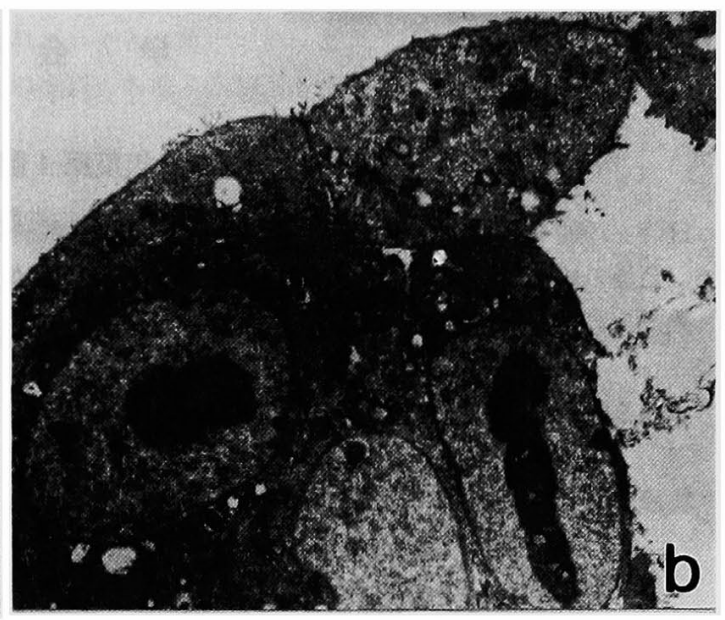

Fig. 1-b. A control mouse blastocyst treated only with an anti-rabbit IgG conjugated with peroxidase. $\times 2500$.

method by WILEY ${ }^{8}$, since the former can show the locality of the substance exactly and more clearly.

\section{References}

1) Haour, F. and B.B. SaXenA, Science, $185: 444-445$. 1974.

2) Channing, C.P., S.L. Stone, C.N. Sakai, F. Haour and B.B. SAXena, J. Reprod. Fert., 54: 215-220. 1978.

3) Varma, S.K., M.Y. DaWood, F. Haour, C. Channing and B.B. Saxena, Fertil. Steril., $31: 68-$ 75. 1979.

4) Fujimoto, S., J.S. Euker, G.D. Riegle and W.R. Dukelow, Proc. Jap. Acad., 51 : 123-125. 1975.

5) Asch, R.H., E.O. FERNANDEz, T.M. Siler-KHOdR and C.J. Pauerstein, Fertil. Steril., 32 : 697-703. 1979.

6) Khan-Dawood, F.S. and M.Y. Dawood, Am. J. Obstet. Gynec., 148 : 359-365. 1984.

7) Asch, R.H., E.O. Fernandez, L.A. Magnasco and C.J. Pauerstein, Fertil. Steril., 29 : 444-446. 1978.

8) WiLEY, L.D., Nature, 252 : 715-716. 1974.

9) Nimura, S. and K. IshidA, Jpn. J. Zootech. Sci., 57 : 540-541. 1986.

10) Dulbecco, R. and M. Vogt, J. exp. Med., 99 : 167182. 1954 . 